\title{
Hemophagocytic Lymphohistiocytosis Gene Mutations in Adult Patients Presenting With CLIPPERS-Like Syndrome
}

Guillaume Taieb, MD, Elsa Kaphan, MD, Claire Duflos, MD, Christine Lebrun-Frénay, MD,

Valérie Rigau, MD, PhD, Eric Thouvenot, MD, PhD, Emeline Duhin-Gand, MD, Romain Lefaucheur, MD, Khe Hoang-Xuan, MD, PhD, Sarah Coulette, MD, Jean Christophe Ouallet, MD, Nicolas Menjot de Champfleur, MD, PhD, Christine Tranchant, MD, PhD, Capucine Picard, MD, PhD, Mathieu Fusaro, MD, Fernando E. Sepulveda, PhD, Pierre Labauge, MD, PhD, and Geneviève de Saint Basile, MD, PhD

Neurol Neuroimmunol Neuroinflamm 2021;8:e970. doi:10.1212/NXI.0000000000000970
Correspondence

Dr. Taieb

taiebguillaume@gmail.com

\section{Abstract}

\section{Objective}

To determine whether adult cases of Chronic Lymphocytic Inflammation with Pontine Perivascular Enhancement Responsive to Steroids (CLIPPERS) may be related to familial hemophagocytic lymphohistiocytosis ( $\mathrm{HLH}$ ) causes, we have screened patients with adultonset CLIPPERS for mutations in primary HLH-associated genes.

\section{Methods}

In our cohort of 36 patients fulfilling the criteria for probable or definite CLIPPERS according to the CLIPPERS-2017 criteria, we conducted a first study on 12 patients who consented to genetic testing. In these 12 patients, systemic $\mathrm{HLH}$ criteria were searched, and genetic analysis of 8 genes involved in primary HLH was performed.

\section{Results}

Four definite and 8 probable CLIPPERS were enrolled $(n=12)$. Mutations involved in HLH were identified in 2 definite and 2 probable CLIPPERS (4/12). Three of them had biallelic PRF1 mutations with reduced perforin expression in natural killer cells. The remaining patient had biallelic UNC13D mutations with cytotoxic lymphocyte impaired degranulation. None of the mutated patients reached the criteria for systemic HLH. During follow-up, 3 of them displayed atypical findings for CLIPPERS, including emergence of systemic non-Hodgkin lymphoma (1/3) and confluent gadolinium-enhancing lesions on brain MRI (3/3).

\section{Conclusions}

In our patients presenting with adult-onset CLIPPERS, one-third have HLH gene mutations. This genetic treatable condition should be searched in patients with CLIPPERS, especially in those presenting with atypical findings.

\footnotetext{
From the Department of Neurology (G.T., P.L.), CHU Montpellier, Hospital Gui de Chauliac; Pôle de Neurosciences Cliniques (E.K.), CHU Timone, Assistance Publique Hôpitaux de Marseille; Clinical Research and Epidemiology Unit (C.D.), CHU Montpellier, University Montpellier; Unité de recherche clinique côte d'azur UR2CA (URRIS) (C.L.-F.), CRCSEP Nice; Department of Pathology (V.R.), CHU Montpellier, Hospital Gui de Chauliac; Department of Neurology (E.T.), CHU Carémeau, Nîmes; Department of Neurology (E.D.-G.), CH Valenciennes; Department of Neurology (R.L.), Rouen University Hospital; APHP (K.H.-X.), Sorbonne Université, IHU, ICM, Department of Neurology Mazarin, Groupe Hospitalier PitiéSalpêtrière, Paris; Department of Neurology (S.C.), CH Gonesse; Department of Neurology (J.C.O.), CHU de Bordeaux; Department of Neuroradiology (N.M.C.), CHU Montpellier, Hospital Gui de Chauliac; Department of Neurology (C.T.), CHU Strasbourg; Université de Paris (C.P., M.F., F.E.S., G.S.B.), Imagine Institute, INSERM U 1163; Centre d'Etude des Déficits Immunitaires (C.P., M.F., G.S.B.), AP-HP, Hôpital Necker-Enfants Malades, Paris; and Centre national de la recherche scientifique (CNRS) (F.E.S.), Paris, France.
} 


\section{Glossary}

CLIPPERS = Chronic Lymphocytic Inflammation with Pontine Perivascular Enhancement Responsive to Steroids; HLH = hemophagocytic lymphohistiocytosis; HSCT = hematopoietic stem cell transplantation; IQR = interquartile range; $N K=$ natural killer.

In 2010, Pittock et al. described 8 patients presenting with symptomatic hindbrain punctate and curvilinear gadoliniumenhancing lesions, responsive but dependent to steroids. These lesions were related to perivascular lymphohistiocytic infiltrates on brainstem biopsies. ${ }^{1}$ The authors named this CNS inflammatory disorder CLIPPERS for Chronic Lymphocytic Inflammation with Pontine Perivascular Enhancement Responsive to Steroids. Since this first description, more than 80 cases have been reported around the world. ${ }^{2-5}$ The mean age at onset was about 50 years (range 13-86 years) with a slight male preponderance. Diagnostic criteria have been proposed in 2017. ${ }^{6}$ In the absence of specific biomarker, these criteria are based on clinical (i.e., subacute brainstem signs and symptoms responsive to steroids), radiologic (i.e., hindbrain punctate and curvilinear gadolinium-enhancing lesions responsive to steroids), and histologic features (i.e., perivascular and parenchymal CNS infiltrates composed by $\mathrm{T}$ cells and macrophages), with lack of alternative diagnosis (e.g., primary angiitis of the CNS, autoimmune gliopathies [related to antimyelin oligodendrocyte glycoprotein or antiglial fibrillary acidic protein antibodies], and CNS lymphoma). ${ }^{7}$ Patients were considered as definite CLIPPERS when all criteria are met and probable CLIPPERS in the absence of histologic confirmation. Recently, mutations in genes associated with familial hemophagocytic lymphohistiocytosis (HLH) have been found in 4 children presenting with isolated CNS involvement sharing some CLIPPERS features. ${ }^{8}$ We anticipated that $\mathrm{HLH}$ restricted to the $\mathrm{CNS}$ could be an interesting candidate to explain some CLIPPERS characteristics such as the presence of numerous histiocytes in the perivascular infiltrates and the striking association with lymphomas. Therefore, we screened adult patients with CLIPPERS for mutations in HLH-associated genes.

\section{Methods}

\section{Standard Protocol Approvals, Registrations, and Patient Consents}

The study protocol was approved by the local investigational review boards and the French Advisory Committee on Medical Research (IRB registration no. 00001072, no. CPP: 2015-03-03/DC 2014-2272). Written informed consent for genetic testing was obtained from each patient analyzed.

\section{Study Population}

Since 2011, University Hospitals of Montpellier collected clinical, radiologic, and histologic data of patients referred as CLIPPERS and displaying hindbrain punctate and/or curvilinear gadolinium enhancements. Thirty-six patients aged 18 years or older met the criteria for probable or definite CLIPPERS according to the CLIPPERS-2017 criteria. ${ }^{6}$ All patients had clinical and radiologic assessments, ancillary tests, and in some of them brain biopsies. The procedure of these investigations was previously described and is summarized in table e-1 (links.lww.com/NXI/A421). ${ }^{7}$

We conducted a first study on 12 patients who consented to genetic testing for familial HLH. Clinical and biological signs of HLH according to the HLH criteria were assessed in each patient at the time of genetic testing (table e-1, links.lww.com/ NXI/A421). ${ }^{9}$ The presence of hemophagocytosis on histologic sections of brain tissue samples was searched at the time of the biopsy in case 2 and retrospectively in the 3 remaining biopsied patients (cases 3, 11, and 12). Finally, clinical and radiologic CLIPPERS features, ancillary tests, and the presence of systemic signs of $\mathrm{HLH}$ were reassessed at each new relapse from the time of genetic sampling and until January 2020 corresponding to the end of follow-up. Clinical and radiologic atypical features for CLIPPERS are summarized in table e-1.

\section{Molecular and Functional Analyses}

Eight genes involved in primary HLH were screened: $P R F 1$, UNC13D, STX11, and STXBP2 associated with familial earlyonset HLH, RAB27A and LYST associated with Griscelli syndrome and Chediak-Higashi syndrome, respectively, and $S A P$ and XIAP associated with X-linked lymphoproliferative syndrome. ${ }^{10,11}$ Genetic screening was performed on DNA isolated from peripheral blood samples using a next-generation sequencing panel that simultaneously analyzed the 8 genes. Identified mutations were confirmed by Sanger sequencing.

An additional blood sample allowed assessing the percentage of circulating activated cytotoxic $\mathrm{T}$ lymphocytes (i.e., CD8+HLA$\mathrm{DR}+\mathrm{T}$ cells that are frequently increase in primary HLH), the serum level of soluble interleukin-2 receptor alpha (CD25), the perforin expression level, and the cytotoxic lymphocyte degranulation ability as previously described. ${ }^{12}$ Perforin expression was assessed on natural killer (NK) cells by flow cytometry, and the level of expression was expressed as the mean fluorescent intensity of each patient sample relative to the control one. Perforin expression and cytotoxic lymphocyte degranulation activity of a mutated patient were compared each time to the one of a healthy control analyzed in the same conditions.

\section{Statistical Analysis}

The quantitative data are presented as median (interquartile range $[\mathrm{IQR}])$, and the qualitative data are presented as number and frequencies or percentages. Median follow-up from the start of the disease to the end of follow-up was calculated for each patient. At the end of follow-up, to assess whether there was a difference between mutated and 
Table 1 Characteristics of Patients With CLIPPERS

\begin{tabular}{|c|c|c|c|c|c|c|c|c|c|}
\hline Case & $\begin{array}{l}\text { Age at onset/ } \\
\text { sex/personal } \\
\text { or familial } \\
\text { background }\end{array}$ & $\begin{array}{l}\text { Diagnosis } \\
\text { at } \\
\text { inclusion }\end{array}$ & $\begin{array}{l}\text { Mutations } \\
\text { in primary } \\
\text { HLH genes }\end{array}$ & $\begin{array}{l}\text { No. of } \\
\text { attacks/ } \\
\text { follow- } \\
\text { up }\end{array}$ & $\begin{array}{l}\text { Spreading } \\
\text { of pontine } \\
\text { Gd+ } \\
\text { lesions }\end{array}$ & $\begin{array}{l}\text { CSF } \\
\text { findings: } \\
\text { WCC per } \\
\mathrm{mm}^{3} / \\
\text { protein } \\
\text { in } \mathrm{g} / \mathrm{L}\end{array}$ & $\begin{array}{l}\text { mRS } \\
\text { score } \\
\text { at the } \\
\text { last } \\
\text { visit }\end{array}$ & $\begin{array}{l}\text { Relapse-free } \\
\text { period since last } \\
\text { attack (mo)/with } \\
\text { or without } \\
\text { treatment }\end{array}$ & $\begin{array}{l}\text { Emergence of } \\
\text { atypical features } \\
\text { for CLIPPERS } \\
\text { (attack number)/ } \\
\text { systemic signs of } \\
\text { HLH }\end{array}$ \\
\hline 1 & 73/F/no & $\begin{array}{l}\text { Probable } \\
\text { CLIPPERS }\end{array}$ & $\begin{array}{l}\text { Biallelic } \\
\text { PRF1 } \\
\text { mutations }\end{array}$ & $\begin{array}{l}2 \\
\text { attacks/ } \\
41 \mathrm{mo}\end{array}$ & $\begin{array}{l}\text { Brain and } \\
\text { spinal cord }\end{array}$ & $\begin{array}{l}8 / 0.8 / \text { no } \\
\text { OCBs }\end{array}$ & 2 & 16/rituximab $1 \mathrm{~g} \times 2$ & $\begin{array}{l}\text { Yes, confluent Gd + } \\
\text { lesions during the } \\
\text { second attack/no } \\
\text { systemic signs }\end{array}$ \\
\hline 2 & 69/M/no & $\begin{array}{l}\text { Definite } \\
\text { CLIPPERS }\end{array}$ & $\begin{array}{l}\text { Biallelic } \\
\text { UNC13D } \\
\text { mutations }\end{array}$ & $\begin{array}{l}2 \\
\text { attacks/ } \\
21 \mathrm{mo}\end{array}$ & Brain & $\begin{array}{l}3 / 0.26 / \mathrm{no} \\
\text { OCBs }\end{array}$ & 5 & $\begin{array}{l}\text { 7/ } \\
\text { polychemotherapy } \\
\text { for systemic NHL }\end{array}$ & $\begin{array}{l}\text { Yes, confluent Gd+ } \\
\text { lesions during the } \\
\text { second attack/ } \\
\text { systemic NHL, no } \\
\text { systemic signs of HLH }\end{array}$ \\
\hline 3 & $\begin{array}{l}\text { 52/M/acute } \\
\text { cerebellitis in } \\
\text { his brother's } \\
\text { granddaughter }\end{array}$ & $\begin{array}{l}\text { Definite } \\
\text { CLIPPERS }\end{array}$ & $\begin{array}{l}\text { Biallelic } \\
\text { PRF1 } \\
\text { mutations }\end{array}$ & $\begin{array}{l}4 \\
\text { attacks/ } \\
120 \mathrm{mo}\end{array}$ & No & $\begin{array}{l}10 / 0.94 / \\
\text { no OCBs }\end{array}$ & 2 & 60/MTX 15 mg/wk & $\begin{array}{l}\text { Yes, confluent Gd+ } \\
\text { lesions during the } \\
\text { second attack/no } \\
\text { systemic signs }\end{array}$ \\
\hline 4 & $42 / \mathrm{M} / \mathrm{no}$ & $\begin{array}{l}\text { Probable } \\
\text { CLIPPERS }\end{array}$ & $\begin{array}{l}\text { Biallelic } \\
\text { PRF1 } \\
\text { mutations }\end{array}$ & $\begin{array}{l}3 \\
\text { attacks/ } \\
43 \mathrm{mo}\end{array}$ & $\begin{array}{l}\text { Brain and } \\
\text { spinal cord }\end{array}$ & $\begin{array}{l}6 / 0.71 / n o \\
\text { OCBs }\end{array}$ & 2 & 8/MTX 25 mg/wk & $\begin{array}{l}\text { No/no systemic signs } \\
\text { of HLH }\end{array}$ \\
\hline 5 & $32 / \mathrm{M} / \mathrm{no}$ & $\begin{array}{l}\text { Probable } \\
\text { CLIPPERS }\end{array}$ & No & $\begin{array}{l}3 \\
\text { attacks/ } \\
118 \mathrm{mo}\end{array}$ & $\begin{array}{l}\text { Brain and } \\
\text { spinal cord }\end{array}$ & $\begin{array}{l}\text { 0/0.74/no } \\
\text { OCBs }\end{array}$ & 1 & $\begin{array}{l}\text { 35/CT } 10 \mathrm{mg} / \mathrm{d} \text { and } \\
\text { MTX } 25 \mathrm{mg} / \mathrm{wk}\end{array}$ & $\begin{array}{l}\text { No/no systemic signs } \\
\text { of HLH }\end{array}$ \\
\hline 6 & 64/M/no & $\begin{array}{l}\text { Probable } \\
\text { CLIPPERS }\end{array}$ & No & $\begin{array}{l}1 \text { attack/ } \\
34 \mathrm{mo}\end{array}$ & $\begin{array}{l}\text { Brain and } \\
\text { spinal cord }\end{array}$ & $\begin{array}{l}6 / 0.47 / \\
\text { OCBs + }\end{array}$ & 0 & $\begin{array}{l}\text { 33/CT } 10 \mathrm{mg} / \mathrm{d}+ \\
\text { MTX } 25 \mathrm{mg} / \mathrm{wk}\end{array}$ & $\begin{array}{l}\text { No/no systemic signs } \\
\text { of HLH }\end{array}$ \\
\hline 7 & 59/M/no & $\begin{array}{l}\text { Probable } \\
\text { CLIPPERS }\end{array}$ & No & $\begin{array}{l}2 \\
\text { attacks/ } \\
36 \mathrm{mo}\end{array}$ & Brain & $\begin{array}{l}\text { 0/0.44/no } \\
\text { OCBs }\end{array}$ & 3 & $3 /$ no treatment & $\begin{array}{l}\text { No/no systemic signs } \\
\text { of HLH }\end{array}$ \\
\hline 8 & 53/F/no & $\begin{array}{l}\text { Probable } \\
\text { CLIPPERS }\end{array}$ & No & $\begin{array}{l}5 \\
\text { attacks/ } \\
108 \mathrm{mo}\end{array}$ & Brain & $\begin{array}{l}5 / 0.58 / \text { no } \\
\text { OCBs }\end{array}$ & 3 & $\begin{array}{l}\text { 62/after } 10 \text { cycles } \\
\text { of CYC }\end{array}$ & $\begin{array}{l}\text { No/no systemic signs } \\
\text { of HLH }\end{array}$ \\
\hline 9 & 48/M/no & $\begin{array}{l}\text { Probable } \\
\text { CLIPPERS }\end{array}$ & No & $\begin{array}{l}3 \\
\text { attacks/ } \\
67 \mathrm{mo}\end{array}$ & Spinal cord & $\begin{array}{l}3 / 0.73 / \text { no } \\
\text { OCBs }\end{array}$ & 1 & 48/MTX $12.5 \mathrm{mg} / \mathrm{wk}$ & $\begin{array}{l}\text { No/no systemic signs } \\
\text { of HLH }\end{array}$ \\
\hline 10 & 24/M/no & $\begin{array}{l}\text { Probable } \\
\text { CLIPPERS }\end{array}$ & No & $\begin{array}{l}2 \\
\text { attacks/ } \\
6 \mathrm{mo}\end{array}$ & No & $\begin{array}{l}10 / 0.83 / \\
\text { no OCBs }\end{array}$ & 0 & $\begin{array}{l}\text { 3/azathioprine } 100 \\
\mathrm{mg} / \mathrm{d}\end{array}$ & $\begin{array}{l}\text { No/no systemic signs } \\
\text { of HLH }\end{array}$ \\
\hline 11 & $61 / \mathrm{M} / \mathrm{no}$ & $\begin{array}{l}\text { Definite } \\
\text { CLIPPERS }\end{array}$ & No & $\begin{array}{l}1 \mathrm{attack} / \\
20 \mathrm{mo}\end{array}$ & Brain & $\begin{array}{l}\text { 0/0.85/no } \\
\text { OCBs }\end{array}$ & 2 & $\begin{array}{l}\text { 19/CT } 20 \mathrm{mg} / \mathrm{d}+ \\
\text { MTX } 12.5 \mathrm{mg} / \mathrm{wk}\end{array}$ & $\begin{array}{l}\text { No/no systemic signs } \\
\text { of } \mathrm{HLH}\end{array}$ \\
\hline 12 & $\begin{array}{l}\text { 69/F/HIV under } \\
\text { HAART }\end{array}$ & $\begin{array}{l}\text { Definite } \\
\text { CLIPPERS }\end{array}$ & No & $\begin{array}{l}2 \\
\text { attacks/ } \\
36 \mathrm{mo}\end{array}$ & Brain & $\begin{array}{l}\text { 0/0.45/ } \\
\text { OCBs + }\end{array}$ & 1 & $16 /$ no treatment & $\begin{array}{l}\text { No/no systemic signs } \\
\text { of HLH }\end{array}$ \\
\hline
\end{tabular}

Abbreviations: CT = prednisone/prednisolone; CLIPPERS = Chronic Lymphocytic Inflammation with Pontine Perivascular Enhancement Responsive to Steroids; $\mathrm{CYC}=$ cyclophosphamide; Gd+ = gadolinium enhancement; HAART = highly active antiretroviral therapy; $\mathrm{mRS}=$ modified Rankin Scale; MTX = methotrexate; $\mathrm{NHL}=$ non-Hodgkin lymphoma; OCB = oligoclonal band; $\mathrm{WCC}=$ white cell count.

nonmutated patients with CLIPPERS, all data collected were compared between these 2 groups of patients. Tests were Fisher exact tests for qualitative variables and Student $t$ tests for quantitative variables, unless for Rankin scale (WilcoxonMann-Whitney). $p$ Values $<0.05$ were considered statistically significant.

\section{Data Availability}

Anonymized data used for this study are available from the corresponding author on reasonable request to any qualified investigator.

\section{Results}

\section{Demographic Characteristics and Initial Assessment of Patients}

In this first study, genetic assessment was performed in 12 patients ( 9 males and 3 females) among 36 patients diagnosed as CLIPPERS (table 1). Five of them have already been reported elsewhere, including 1 patient shown here to carry HLH gene mutations. ${ }^{4,713}$ According to the CLIPPERS-2017 criteria, 8 patients met the clinical and radiologic CLIPPERS criteria and were considered as probable CLIPPERS, and 4 
Table 2 HLH Evaluation in the Patients Carrying Mutation in Primary HLH-Related Genes

\begin{tabular}{|c|c|c|c|c|}
\hline Patient & 1 & 2 & 3 & 4 \\
\hline Mutation & $\begin{array}{l}\text { PRF1 c. 272C>T } \\
\text { (p.A91V) homozygous }\end{array}$ & $\begin{array}{l}\text { UNC13D c.919C>T (p.Q307*) and } \\
\text { c.2038C }>\text { T (p.R680W) }\end{array}$ & $\begin{array}{l}\text { PRF1 c. } 116 \mathrm{C}>\mathrm{A}(\mathrm{p} . \mathrm{P} 39 \mathrm{H}) \\
\text { and c.272C }>\mathrm{T}(\text { p.A91V) }\end{array}$ & $\begin{array}{l}\text { PRF1 c. } 82 \mathrm{C}>\mathrm{T} \text { (p.R28C) and } \\
\text { c.272C }>\text { T (p.A91V) }\end{array}$ \\
\hline \multicolumn{5}{|l|}{ Systemic HLH evaluation } \\
\hline Fever $>38.0^{\circ} \mathrm{C}$ & No & No & No & No \\
\hline Splenomegaly & No & No & No & No \\
\hline $\mathrm{Hb}<90 \mathrm{~g} / \mathrm{L}$ & No & No & No & No \\
\hline Plt $<100 \times 10^{9} / \mathrm{L}$ & No & No & No & No \\
\hline $\mathrm{Neu}<1.0 \times 10^{9} / \mathrm{L}$ & No & No & No & No \\
\hline $\mathrm{Tg} \geq 3.0 \mathrm{mmol} / \mathrm{L}$ & No & No & No & No \\
\hline $\mathrm{Fg} \leq 1.5 \mathrm{~g} / \mathrm{L}$ & No & No & No & No \\
\hline Ferritin $\geq 500 \mu \mathrm{g} / \mathrm{L}$ & No & 519 & No & No \\
\hline Hemophago BM & No & No & ND & No \\
\hline HLA DR+/CD8+ \% (normal $\leq 10)$ & 22 & 16 & 1 & 1 \\
\hline $\begin{array}{l}\text { Soluble IL-2 receptor }(\mathrm{pg} / \mathrm{mL} \text {, } \\
\text { normal }<2,400)\end{array}$ & 1,980 & 1,241 & 1,500 & 1,200 \\
\hline $\begin{array}{l}\text { NK cell perforin expression } \\
\text { level (MFI \% of control) }\end{array}$ & Decreased (38\%) & NA & Decreased (25\%) & Decreased (38\%) \\
\hline $\begin{array}{l}\text { Cytotoxic lymphocyte } \\
\text { degranulation }\end{array}$ & NA & Decreased & NA & NA \\
\hline
\end{tabular}

Abbreviations: $\mathrm{BM}=$ bone marrow; Fg = fibrinogen; $\mathrm{Hb}=$ hemoglobin; Hemophago = hemophagocytosis; HLH = hemophagocytic lymphohistiocytosis; MFI = mean fluorescent intensity; NA = not applicable; ND = not done; Neu = neutrophils; Plt = platelets; Tg = triglycerides.

First evaluation for systemic HLH and genetic assessment were performed before the development of atypical findings for CLIPPERS in all patients except for patient 3. Systemic HLH evaluation was (re)assessed when atypical features emerged in all patients except for patient 4 . Assessment of immunologic functions was performed after the development of atypical findings for CLIPPERS in all patients except for patient 4.

patients met the clinical, radiologic, and histologic criteria and were considered as definite CLIPPERS. The median age at onset was 56 (IQR 45-66.5) years. Patients were followed during a median of 38.5 months (IQR 27.5-87.5 months), and the median number of attacks per patient was 2 (IQR 2-3).

\section{Description and Follow-up of Mutated Patients With CLIPPERS}

Biallelic variations in genes involved in primary HLH were identified in 2 definite and 2 probable CLIPPERS (cases 1-4) (table 2). These 4 patients with nonconsanguineous parents were Caucasians. Three of them carried PRF1 variations (compound heterozygous in 2 [cases 3 and 4] and homozygous in 1 [case 1]), previously reported to partially impair lymphocyte cytotoxicity. ${ }^{14-16}$ Hence, a reduced perforin expression was observed in the patients' NK cells (figure 2 ). The fourth patient (case 2) carried compound heterozygous variations in $U N C 13 D$, i.e., a nonsense mutation and a missense mutation predicted to be likely pathogenic (table 2 and figure 2). As a result, patient's cytotoxic T lymphocyte degranulation was partially impaired (figure 2). Two patients (cases 1 and 2) had a slight increased in the percentage of circulating activated CD8 T cells (22\% and 16\% respectively, normal $\leq 10$ of CD8 $\mathrm{HLA}_{-} \mathrm{DR}^{+}$; table 2) supporting a T lymphocyte-driven disease as observed in primary HLH. ${ }^{17}$ None of the mutated patients had history of recurrent infections or severe viral infection. After a median follow-up of 42 months (IQR 31-81.5 months), 3 of them displayed atypical findings for CLIPPERS, shifting the initial diagnosis from CLIPPERS to non-CLIPPERS. The median time interval to the development of atypical features was 16 months (minimum 13, maximum 24). Case 2 developed a systemic B-cell non-Hodgkin lymphoma requiring a polychemotherapy (table 1). In cases 1 to 3 , brain MRI showed confluent gadolinium-enhancing lesions on postcontrast $\mathrm{T} 1$-weighted images with large T2 hyperintensities on corresponding areas (figure 1). Brain biopsies targeting these atypical enhancing lesions in cases 2 and 3 showed characteristic perivascular lymphohistiocytic infiltrates seen in CLIPPERS with a predominance of CD4 $\mathrm{T}$ cells. There were neither unusual pathologic features nor signs of hemophagocytosis. As usually described in CLIPPERS, no patient relapsed when prednisone was above $30 \mathrm{mg}$ per day. The median modified Rankin Scale score at the last visit was 2 (IQR 2-3.5). These mutated patients did not reach the criteria for systemic HLH (table 2). Except systemic lymphoma in case 2, no triggering factor for $\mathrm{HLH}$ was found in the 3 remaining mutated patients. 
Figure 1 Radiologic Features of Mutated Patients With CLIPPERS

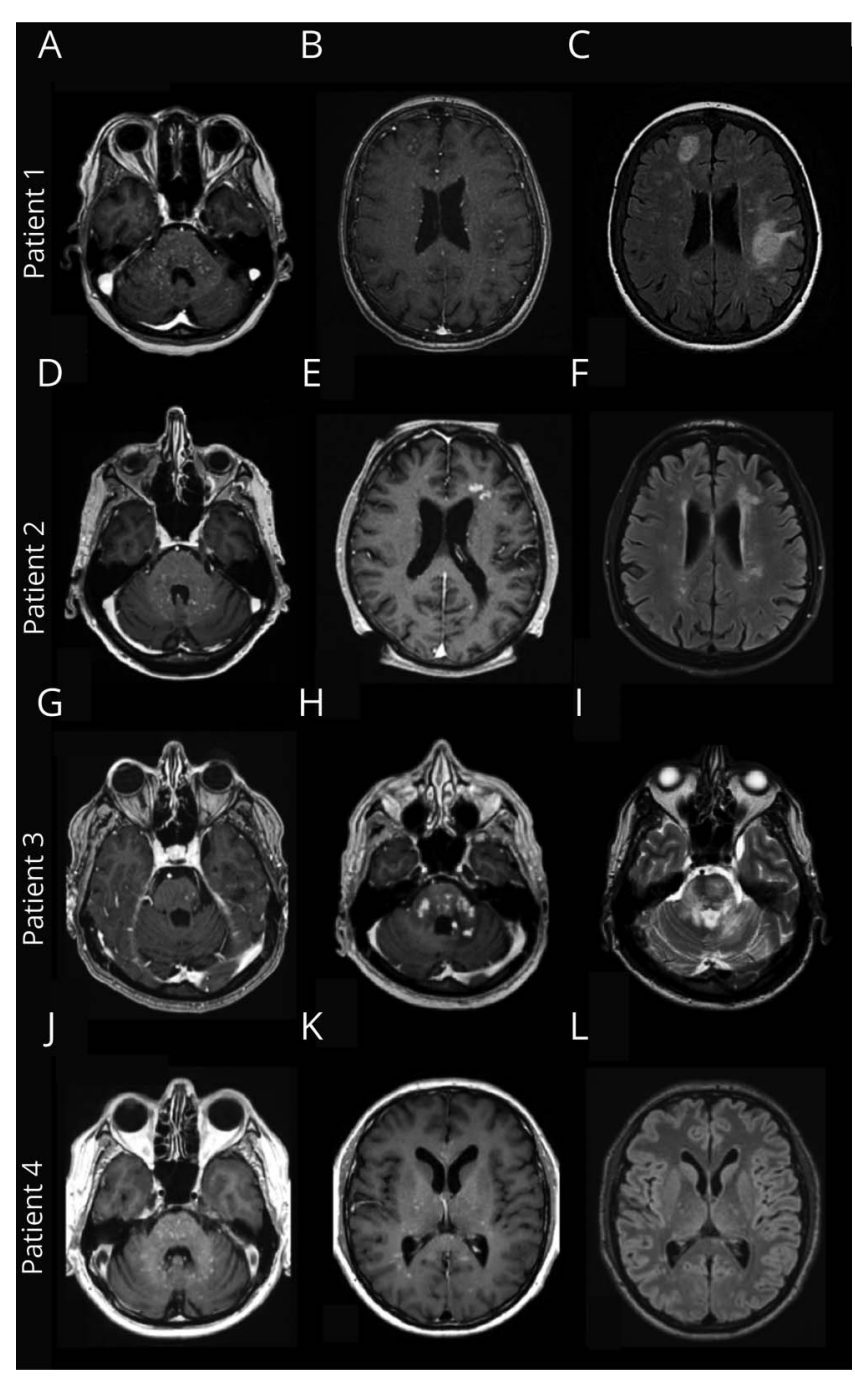

MRI at the first evaluation showed in all patients typical pontine punctate and curvilinear gadolinium enhancements on postcontrast T1WI (A, D, G, and J). In patients 1 to $3, \mathrm{MRI}$ at the second attack displayed atypical confluent gadolinium-enhancing lesions on postcontrast T1WI $(B, E$, and $H)$ with large T2/FLAIR hyperintensities on corresponding areas (C, F, and I). In patient 4 $\mathrm{MRI}$ at the second and third attacks still showed typical punctate gadolinium enhancements on postcontrast T1WI (K) with punctate T2/FLAIR hyperintensities on corresponding areas (L). CLIPPERS = Chronic Lymphocytic Inflammation with Pontine Perivascular Enhancement Responsive to Steroids; FLAIR = fluid-attenuated inversion recovery.

Regarding familial background of case 3, his brother's granddaughter displayed a self-limited acute cerebellitis of unknown origin, and genetic screening showed a monoallelic mutation in PRF1.

\section{Description and Follow-up of Nonmutated Patients With CLIPPERS}

In patients with CLIPPERS without identified mutation in the primary HLH genes analyzed (cases 5-12), 2 were definite CLIPPERS and 6 were probable CLIPPERS (table 1). After a median follow-up of 36 months (IQR 27-87.5), atypical clinical, radiologic, and/or histologic findings for CLIPPERS were not seen. In case 5, a nodular spinal cord enhancing lesion at the cervical level was seen during the first attack. This lesion disappeared under steroid therapy and did not relapse during the 2 further attacks (118 months of follow-up). As usually described in CLIPPERS, no patient relapsed when prednisone was above $30 \mathrm{mg}$ per day. The median modified Rankin Scale score at the last visit was 1 (IQR 0.5-2.5). None of the nonmutated patients reached the criteria for systemic HLH. Except HIV type 1 in case 12, no triggering factor for $\mathrm{HLH}$ was found. These patients had no significant familial background of CNS disorder or history of hemophagocytosis.

\section{Comparison Between Mutated and Nonmutated Patients With CLIPPERS}

Data including age at onset, number of attacks, duration of follow-up, modified Rankin Scale score, presence of pontine gadolinium-enhancing lesions spreading (i.e., brain and/or spinal cord), CSF analysis, presence of systemic signs of $\mathrm{HLH}$, and presence of clinical, radiologic, and/or histologic atypical features for CLIPPERS at the last follow-up were compared between mutated and nonmutated patients with CLIPPERS (table 3). Only the presence of atypical features for CLIPPERS was significantly more frequent in mutated patients ( $p$ $=0.02)$.

\section{Discussion}

Primary HLH gene mutations were found in 33\% of our patients presenting with adult-onset CLIPPERS. The mutated patients herein reported had no familial history of HLH or chronic CNS disorder. In addition, none of them met the criteria for the diagnosis of systemic $\mathrm{HLH}$, although all exhibited a deficit in a protein involved in lymphocyte cytotoxicity. The reason for the CNS-restricted manifestations in these patients is not fully understood. It has been well recognized that systemic HLH manifestations due to a functional defect in $\mathrm{T}$ lymphocytes and NK cells cytotoxicity, result from impaired antigen clearance. ${ }^{10,18}$ Antigen persistence leads to lymphocyte and macrophage overactivation, systemic inflammatory cytokine release, and multiorgan failure. In the context of systemic HLH, about half of the patients have CNS involvement. ${ }^{19}$ However, because the diagnosis of HLH requires systemic signs, the prevalence of CNS-restricted involvement with underlying $\mathrm{HLH}$ pathophysiology is not determined.

It is noticeable that the perforin mutations identified in our patients are all hypomorphic gene variants preserving some protein function. Through different combinations, these mutations have been previously associated with late or atypical forms of HLH or to malignancies. ${ }^{14-16}$ Degranulation activity of cytotoxic cells is also partially preserved in the patient carrying UNC13D mutations. In these situations, the residual lymphocyte cytotoxicity may be sufficient to prevent acute systemic HLH development in response to most environmental triggers, but not in response to specific triggers 
A

P3

P4

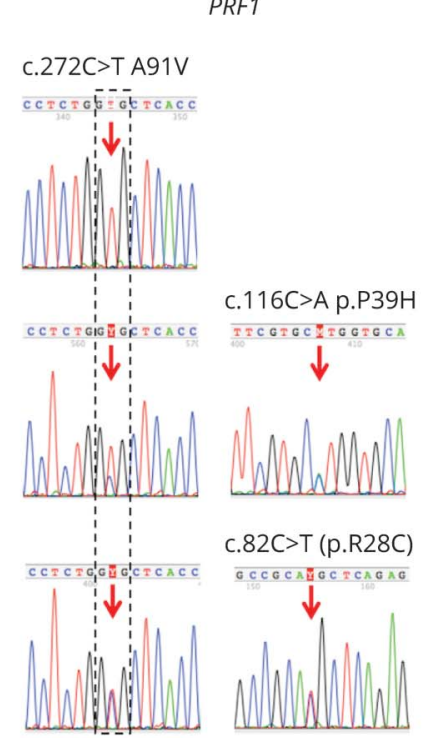

UNC13D

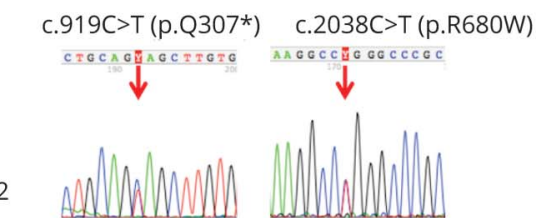

B
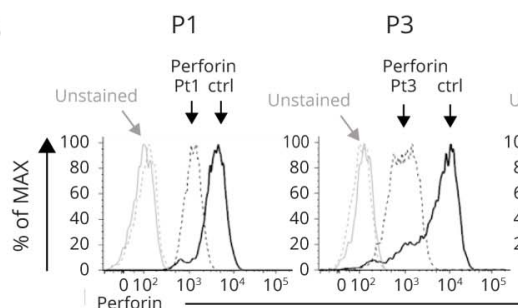

P4

Perforin

Pt4ctr

$\perp$

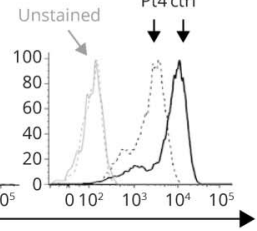

C

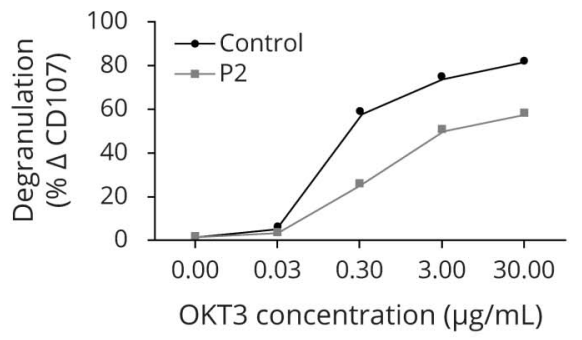

(A) Sanger sequencing chromatogram depicting the homozygous (in P1) and heterozygous (in P2-4) mutations identified in PRF1 and UNC13D genes; (B) Flow cytometric analysis of perforin expression at the surface of natural killer cells from P1, P3, and P4. Histograms show overlays of unstained (gray) and perforin stained natural killer cells (black) from each patient (doted line) and a control (solid line) performed in the same experiment. (C) Degranulation of cytotoxic $T$ lymphoblasts from patient P2 (gray curve) compared with control (black curve). Induced CD107 surface expression on cytotoxic T lymphoblasts activated by increased concentration of anti-CD3 (OKT3) is partially impaired in P2.

localized in some organs, particularly in the CNS. We cannot exclude in our patients the existence of specific neuroinflammatory events and/or the contribution of additional modifying factors that favored the onset of CNS-restricted HLH in this deficient cytotoxicity context.

Of interest, three-fourth of the mutated patients subsequently developed atypical radiologic features for CLIPPERS including confluent gadolinium-enhancing lesions with large T2 hyperintensities. In one of them, a systemic B-cell nonHodgkin lymphoma appeared 21 months after disease onset. In this patient, the impaired lymphocyte cytotoxicity may have contributed to the emergence of B-cell lymphoma. ${ }^{15}$ In our study, the emergence of atypical CLIPPERS findings was only seen in the mutated patients. However, one of the mutated patients still met the CLIPPERS criteria despite 2 relapses and 43 months of follow-up. Emergence of atypical features for CLIPPERS may therefore represent a discriminating sign although not absolute given it absence in 1 patient harboring mutations in familial HLH-associated genes. Atypical features may also take longer to appear in some cases. Thus, screening for mutations in genes related to primary HLH should be fostered in all patients presenting with CLIPPERS.
Determination of such genetic alterations in patients with CLIPPERS is significant because hematopoietic stem cell transplantation (HSCT) is currently the only curative treatment for primary HLH. Besides, new specific therapies targeting cellular or soluble immune effectors of HLH are increasingly available, that may be worth to consider. ${ }^{20} \mathrm{Re}-$ cently, 4 children presenting with chronic CNS inflammatory disorders associated with mutations in familial HLH genes achieved sustained remission after unrelated donor HSCT. ${ }^{8}$ Of interest, one of them met the CLIPPERS criteria and subsequently developed confluent gadolinium-enhancing lesions with large T2 hyperintensities before the graft. Although the place of HSCT remains to be defined, this therapy should be considered in patients with CLIPPERS features harboring mutations in primary HLH genes, who become resistant to steroids and immunosuppressive therapies. ${ }^{21}$ The present study raises another issue: whether CLIPPERS is a disease or a syndrome. $^{22-24}$ Our data strongly support the idea that CLIPPERS is a heterogeneous condition, potentially with different pathways of pathogenesis, resulting in similar clinical presentation. No mutations in the primary HLH genes were detected in $67 \%$ of our patients with CLIPPERS. We cannot totally exclude that some of them carried undetectable mutations in these genes. Alternatively, they may have mutations 
Table 3 Comparison Between Mutated and Nonmutated Patients With CLIPPERS

\begin{tabular}{|c|c|c|c|}
\hline & $\begin{array}{l}\text { Nonmutated patients with CLIPPERS } \\
(\mathrm{n}=8)\end{array}$ & $\begin{array}{l}\text { Mutated patients with CLIPPERS } \\
(n=4)\end{array}$ & $\begin{array}{l}p \\
\text { Value }\end{array}$ \\
\hline Age at onset & $56.00(40.00-62.50)$ & $60.50(47.00-71.00)$ & 0.43 \\
\hline No. of attacks & $2.00(1.50-3.00)$ & $2.50(2.00-3.50)$ & 0.62 \\
\hline Follow-up (mo) & $36.00(27.00-87.50)$ & $42.00(31.00-81.50)$ & 0.91 \\
\hline mRS score at the last visit (relapse-free period) & $1.00(0.50-2.50)$ & $2.00(2.00-3.50)$ & 0.16 \\
\hline $\begin{array}{l}\text { Pontine Gd+ spreading to the brain and/or spinal cord, } \mathbf{n} \\
\text { (\%col) }\end{array}$ & $6(75.00)$ & $3(75.00)$ & 1.00 \\
\hline CSF white cell count per $\mathrm{mm}^{3}$ & $1.50(0.00-5.50)$ & $7.00(4.50-9.00)$ & 0.11 \\
\hline CSF protein in gram per liter & $0.66(0.46-0.79)$ & $0.76(0.49-0.87)$ & 0.76 \\
\hline CSF OCBs, $\mathrm{n}$ (\%col) & $2(25.00)$ & $1(25.00)$ & 1.00 \\
\hline Emergence of atypical features for CLIPPERS, $n$ (\%col) & $0(0.00)$ & $3(75.00)$ & $0.02^{a}$ \\
\hline \multicolumn{4}{|c|}{$\begin{array}{l}\text { Abbreviations: CLIPPERS = Chronic Lymphocytic Inflammation with Pontine Perivascular Enhancement Responsive to Steroids; Gd+ = gadolinium en- } \\
\text { hancement; } \mathrm{mRS}=\text { modified Rankin Scale; OCB = oligoclonal band. } \\
\text { Values are } \mathrm{n}(\% \text { col) or median (Q1-Q3). Tests are Fisher exact tests for qualitative variables and Student } t \text { tests for quantitative variables, unless for Ranking } \\
\text { scale (Wilcoxon-Mann-Whitney). } \\
\text { a } p \text { Values }<0.05 \text { are considered statistically significant. }\end{array}$} \\
\hline
\end{tabular}

in other uncharacterized genes and/or have been exposed to environmental factors triggering HLH features in CNS. Following this line, CLIPPERS could reflect either a primary or a secondary form of CNS-restricted HLH. Among our nonmutated patients, 1 had HIV. This virus is known to potentially trigger secondary $\mathrm{HLH}^{25}$ Other possible triggers associated with CLIPPERS were also described as triggers of HLH such as Epstein-Barr virus, systemic lymphomas, and more recently histiocytic sarcoma. ${ }^{26-28}$

Given the small number of patients genetically tested in our cohort, additional studies are needed to better evaluate the prevalence of mutations in genes related to primary HLH in the patients presenting with CLIPPERS. In addition, because signs of HLH were not systematically searched in the untested patients of our cohort, we cannot totally rule out a selection bias.

Nevertheless, we thought that primary HLH should be searched in patients with CLIPPERS, especially in those presenting with atypical findings. Further studies may help to better delineate the different causes and mechanisms leading to CLIPPERS features in patients with primary HLH.

\section{Acknowledgment}

Benjamin Taieb helped design the figures. The authors are grateful to Frederic Guerin, Nathalie Lambert, Virginie Grandin, and Corinne Jacques for their technical assistance.

\section{Study Funding}

This work was supported by INSERM and the association LHF Espoir.

\section{Disclosure}

The authors report no disclosures relevant to the manuscript. Go to Neurology.org/NN for full disclosures.

\section{Publication History}

Received by Neurology: Neuroimmunology \& Neuroinflammation September 29, 2020. Accepted in final form January 5, 2021.

Appendix Authors

\begin{tabular}{|c|c|c|}
\hline Name & Location & Contribution \\
\hline $\begin{array}{l}\text { Guillaume Taieb, } \\
\text { MD }\end{array}$ & $\begin{array}{l}\text { University of } \\
\text { Montpellier, } \\
\text { France }\end{array}$ & $\begin{array}{l}\text { Full access to all of the data in the } \\
\text { study and takes responsibility for } \\
\text { the integrity of the data and the } \\
\text { accuracy of the data analysis; } \\
\text { study concept and design; } \\
\text { acquisition, analysis, or } \\
\text { interpretation of data; drafting of } \\
\text { the manuscript; and critical } \\
\text { revision of the manuscript for } \\
\text { important intellectual content }\end{array}$ \\
\hline Elsa Kaphan, MD & $\begin{array}{l}\text { University of } \\
\text { Marseille, } \\
\text { France }\end{array}$ & $\begin{array}{l}\text { Acquisition, analysis, or } \\
\text { interpretation of data; critical } \\
\text { revision of the manuscript for } \\
\text { important intellectual content; } \\
\text { and drafting of the manuscript }\end{array}$ \\
\hline Claire Duflos, MD & $\begin{array}{l}\text { University of } \\
\text { Montpellier, } \\
\text { France }\end{array}$ & $\begin{array}{l}\text { Acquisition, analysis, or } \\
\text { interpretation of data; critical } \\
\text { revision of the manuscript for } \\
\text { important intellectual content; } \\
\text { drafting of the manuscript; and } \\
\text { statistical analysis }\end{array}$ \\
\hline
\end{tabular}

\begin{tabular}{ll}
\hline Christine Lebrun- & University of \\
Frénay, MD & Nice, France
\end{tabular}

Acquisition, analysis, or interpretation of data; critical revision of the manuscript for important intellectual content; and drafting of the manuscript

\begin{tabular}{lll}
\hline $\begin{array}{l}\text { Valérie Rigau, MD, } \\
\text { PhD }\end{array}$ & $\begin{array}{l}\text { University of } \\
\text { Montpellier, } \\
\text { France }\end{array}$ & $\begin{array}{l}\text { Acquisition, analysis, or } \\
\text { interpretation of data and critical } \\
\text { revision of the manuscript for } \\
\text { important intellectual content }\end{array}$ \\
\hline
\end{tabular}


Appendix (continued)

\begin{tabular}{lll}
\hline Name & Location & Contribution \\
\hline Eric Thouvenot, & University of & $\begin{array}{l}\text { Acquisition, analysis, or } \\
\text { MD, PhD }\end{array}$ \\
Nîmes, France & $\begin{array}{l}\text { interpretation of data and critical } \\
\text { revision of the manuscript for } \\
\text { important intellectual content }\end{array}$
\end{tabular}

\begin{tabular}{lll}
\hline Emeline Duhin- & Valenciennes & $\begin{array}{l}\text { Acquisition, analysis, or } \\
\text { interpretation of data and critical } \\
\text { Gand, MD }\end{array}$ \\
& Hospital, & $\begin{array}{l}\text { revision of the manuscript for } \\
\text { important intellectual content }\end{array}$
\end{tabular}

\begin{tabular}{lll}
\hline Romain & University of & Acquisition, analysis, or \\
Lefaucheur, MD & Rouen, France & $\begin{array}{l}\text { interpretation of data and critical } \\
\text { revision of the manuscript for } \\
\text { important intellectual content }\end{array}$ \\
& &
\end{tabular}

\begin{tabular}{|c|c|c|}
\hline $\begin{array}{l}\text { Khe Hoang-Xuan, } \\
\text { MD, PhD }\end{array}$ & $\begin{array}{l}\text { University of } \\
\text { Sorbonne, } \\
\text { France }\end{array}$ & $\begin{array}{l}\text { Acquisition, analysis, or } \\
\text { interpretation of data and critical } \\
\text { revision of the manuscript for } \\
\text { important intellectual content }\end{array}$ \\
\hline $\begin{array}{l}\text { Sarah Coulette, } \\
\text { MD }\end{array}$ & $\begin{array}{l}\text { University of } \\
\text { Gonesse, } \\
\text { France }\end{array}$ & $\begin{array}{l}\text { Acquisition, analysis, or } \\
\text { interpretation of data and critical } \\
\text { revision of the manuscript for } \\
\text { important intellectual content }\end{array}$ \\
\hline $\begin{array}{l}\text { Jean Christophe } \\
\text { Ouallet, MD }\end{array}$ & $\begin{array}{l}\text { University of } \\
\text { Bordeaux, } \\
\text { France }\end{array}$ & $\begin{array}{l}\text { Acquisition, analysis, or } \\
\text { interpretation of data and critical } \\
\text { revision of the manuscript for } \\
\text { important intellectual content }\end{array}$ \\
\hline $\begin{array}{l}\text { Nicolas Menjot de } \\
\text { Champfleur, MD, } \\
\text { PhD }\end{array}$ & $\begin{array}{l}\text { University of } \\
\text { Montpellier, } \\
\text { France }\end{array}$ & $\begin{array}{l}\text { Acquisition, analysis, or } \\
\text { interpretation of data and critical } \\
\text { revision of the manuscript for } \\
\text { important intellectual content }\end{array}$ \\
\hline
\end{tabular}

\begin{tabular}{lll}
\hline Christine & University of & $\begin{array}{l}\text { Acquisition, analysis, or } \\
\text { interpretation of data and critical } \\
\text { Tranchant, MD, }\end{array}$ \\
PhD & Strasbourg, & $\begin{array}{l}\text { revision of the manuscript for } \\
\text { important intellectual content }\end{array}$
\end{tabular}

\begin{tabular}{lll}
\hline Capucine Picard, & Imagine & $\begin{array}{l}\text { Acquisition, analysis, or } \\
\text { interpretation of data and critical } \\
\text { MD, PhD }\end{array}$ \\
& Institute, & $\begin{array}{l}\text { revision of the manuscript for } \\
\text { important intellectual content }\end{array}$ \\
& &
\end{tabular}

\begin{tabular}{lll}
\hline $\begin{array}{l}\text { Mathieu Fusaro, } \\
\text { MD }\end{array}$ & $\begin{array}{l}\text { Imagine } \\
\text { Institute, } \\
\text { France }\end{array}$ & $\begin{array}{l}\text { Acquisition, analysis, or } \\
\text { interpretation of data and critical } \\
\text { revision of the manuscript for } \\
\text { important intellectual content }\end{array}$ \\
\end{tabular}

\begin{tabular}{lll}
\hline Fernando E. & Imagine & Acquisition, analysis, or \\
Sepulveda, PhD & Institute, & $\begin{array}{l}\text { interpretation of data and critical } \\
\text { revision of the manuscript for } \\
\text { important intellectual content }\end{array}$ \\
& &
\end{tabular}

\begin{tabular}{lll}
\hline Pierre Labauge, & University of & Acquisition, analysis, or \\
MD, PhD & Montpellier, & $\begin{array}{l}\text { interpretation of data; critical } \\
\text { revision of the manuscript for }\end{array}$ \\
& France & important intellectual content; \\
& and drafting of the manuscript
\end{tabular}

\begin{tabular}{ll}
\hline Geneviève de & Imagine \\
Saint Basile, MD, & Institute, \\
PhD & France
\end{tabular}

Full access to all of the data in the study and takes responsibility for the integrity of the data and the accuracy of the data analysis; study concept and design; acquisition, analysis, or interpretation of data; drafting of the manuscript; and critical revision of the manuscript for important intellectual content

\section{References}

1. Pittock SJ, Debruyne J, Krecke KN, et al. Chronic lymphocytic inflammation with pontine perivascular enhancement responsive to steroids (CLIPPERS). Brain 2010;133:2626-2634.

2. Kastrup O, van de Nes J, Gasser T, Keyvani K. Three cases of CLIPPERS: a serial clinical, laboratory and MRI follow-up study. J Neurol 2011;258:2140-2146.

3. Simon NG, Parratt JD, Barnett MH, et al. Expanding the clinical, radiological and neuropathological phenotype of chronic lymphocytic inflammation with pontine perivascular enhancement responsive to steroids (CLIPPERS). J Neurol Neurosurg Psychiatry 2012;83:15-22.

4. Taieb G, Duflos C, Renard D, et al. Long-term outcomes of CLIPPERS (chronic lymphocytic inflammation with pontine perivascular enhancement responsive to steroids) in a consecutive series of 12 patients. Arch Neurol 2012;69:847-855.

5. Kerrn-Jespersen BM, Lindelof M, Illes Z, et al. CLIPPERS among patients diagnosed with non-specific CNS neuroinflammatory diseases. J Neurol Sci 2014;343:224-227.

6. Tobin WO, Guo Y, Krecke KN, et al. Diagnostic criteria for chronic lymphocytic inflammation with pontine perivascular enhancement responsive to steroids (CLIPPERS). Brain 2017;140:2415-2425.

7. Taieb G, Mulero P, Psimaras D, et al. CLIPPERS and its mimics: evaluation of new criteria for the diagnosis of CLIPPERS. J Neurol Neurosurg Psychiatry 2019;90:1027-1038.

8. Benson LA, Li H, Henderson LA, et al. Pediatric CNS-isolated hemophagocytic lymphohistiocytosis. Neurol Neuroimmunol Neuroinflamm 2019;6:e560.

9. Henter JI, Horne A, Arico M, et al. HLH-2004: diagnostic and therapeutic guidelines for hemophagocytic lymphohistiocytosis. Pediatr Blood Cancer 2007;48:124-131.

10. Pachlopnik Schmid J, Cote M, Menager MM, et al. Inherited defects in lymphocyte cytotoxic activity. Immunolo Rev 2010;235:10-23.

11. de Saint Basile G, Menasche G, Latour S. Inherited defects causing hemophagocytic lymphohistiocytic syndrome. Ann NY Acad Sci 2011;1246:64-76.

12. Rohr J, Beutel K, Maul-Pavicic A, et al. Atypical familial hemophagocytic lymphohistiocytosis due to mutations in UNC13D and STXBP2 overlaps with primary immunodeficiency diseases. Haematologica 2010;95:2080-2087.

13. Lefaucheur R, Bourre B, Ozkul-Wermester O, et al. Stroke mimicking relapse in a patient with CLIPPERS syndrome. Acta Neurol Belgica 2015;115:735-736.

14. Voskoboinik I, Sutton VR, Ciccone A, et al. Perforin activity and immune homeostasis: the common $\mathrm{A} 91 \mathrm{~V}$ polymorphism in perforin results in both presynaptic and postsynaptic defects in function. Blood 2007;110:1184-1190.

15. Chia J, Yeo KP, Whisstock JC, et al. Temperature sensitivity of human perforin mutants unmasks subtotal loss of cytotoxicity, delayed FHL, and a predisposition to cancer. Proc Natl Acad Sci USA 2009;106:9809-9814.

16. Trapani JA, Thia KY, Andrews M, et al. Human perforin mutations and susceptibility to multiple primary cancers. Oncoimmunology 2013;2:e24185.

17. Ammann S, Lehmberg K, Zur Stadt U, et al. Primary and secondary hemophagocytic lymphohistiocytosis have different patterns of T-cell activation, differentiation and repertoire. Eur J Immunol 2017;47:364-373.

18. Sepulveda FE, de Saint Basile G. Hemophagocytic syndrome: primary forms and predisposing conditions. Curr Opin Immunol 2017;49:20-26.

19. Horne A, Trottestam H, Arico M, et al. Frequency and spectrum of central nervous system involvement in 193 children with haemophagocytic lymphohistiocytosis. Br J Haematol 2008;140:327-335.

20. Wegehaupt O, Wustrau K, Lehmberg K, Ehl S. Cell versus cytokine: directed therapies for hemophagocytic lymphohistiocytosis (HLH) in inborn errors of immunity. Front Immunol 2020;11:808.

21. Taieb G, Allou T, Labauge P. Therapeutic approaches in CLIPPERS. Curr Treat Options Neurol 2017;19:17

22. Kira J. The expanding phenotype of CLIPPERS: is it a disease or a syndrome? J Neurol Neurosurg Psychiatry 2012;83:2-3.

23. Buttmann M, Metz I, Brecht I, Brück W, Warmuth-Metz M. Atypical chronic lymphocytic inflammation with pontocerebellar perivascular enhancement responsive to steroids (CLIPPERS), primary angiitis of the CNS mimicking CLIPPERS or overlap syndrome? A case report. J Neurol Sci 2013;324:183-186.

24. Dudesek A, Rimmele F, Tesar S, et al. CLIPPERS: chronic lymphocytic inflammation with pontine perivascular enhancement responsive to steroids. Review of an increasingly recognized entity within the spectrum of inflammatory central nervous system disorders. Clin Exp Immunol 2014;175:385-396.

25. Otrock ZK, Eby CS. Clinical characteristics, prognostic factors, and outcomes of adult patients with hemophagocytic lymphohistiocytosis. Am J Hematol 2015;90:220-224.

26. Ma Y, Sun X, Li W, et al. Chronic lymphocytic inflammation with pontine perivascular enhancement responsive to steroids (CLIPPERS) with intracranial Epstein-Barr virus infection: a case report. Medicine 2016;95:e5377.

27. Zhang $\mathrm{L}$, Liu $\mathrm{XH}$, Jin $\mathrm{F}$, et al. Chronic lymphocytic inflammation with pontine perivascular enhancement responsive to steroids (CLIPPERS) associated with or without lymphoma: comparison of clinical features and risk factors suggestive of underlying lymphomas. J Clin Neurosci 2019;66:156-164.

28. Li Z, Jiang Z, Ouyang S, et al. CLIPPERS, a syndrome of lymphohistiocytic disorders. Mult Scler Relat Disord 2020;42:102063. 


\title{
Neurology ${ }^{\oplus}$ \\ Neuroimmunology \& Neuroinflammation
}

\author{
Hemophagocytic Lymphohistiocytosis Gene Mutations in Adult Patients Presenting \\ With CLIPPERS-Like Syndrome \\ Guillaume Taieb, Elsa Kaphan, Claire Duflos, et al. \\ Neurol Neuroimmunol Neuroinflamm 2021;8; \\ DOI 10.1212/NXI.0000000000000970
}

This information is current as of March 3, 2021

Neurol Neuroimmunol Neuroinflamm is an official journal of the American Academy of Neurology.

Published since April 2014, it is an open-access, online-only, continuous publication journal. Copyright

Copyright $\left({ }^{\circ} 2021\right.$ The Author(s). Published by Wolters Kluwer Health, Inc. on behalf of the American

Academy of Neurology.. All rights reserved. Online ISSN: 2332-7812.

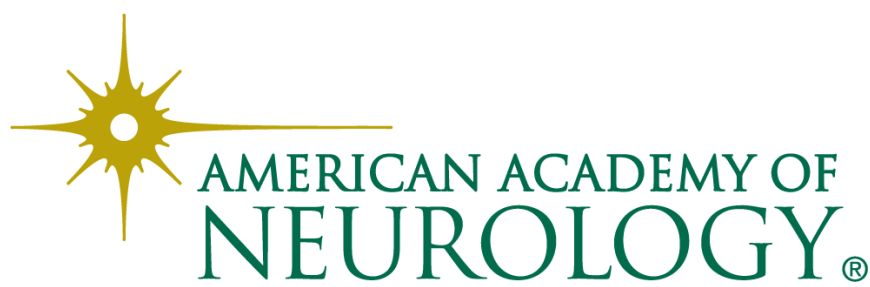




\section{Updated Information \& Services}

References

Citations

Subspecialty Collections

Permissions \& Licensing

Reprints including high resolution figures, can be found at: http://nn.neurology.org/content/8/3/e970.full.html

This article cites 28 articles, 7 of which you can access for free at: http://nn.neurology.org/content/8/3/e970.full.html\#\#ref-list-1

This article has been cited by 2 HighWire-hosted articles: http://nn.neurology.org/content/8/3/e970.full.html\#\#otherarticles

This article, along with others on similar topics, appears in the following collection(s):

\section{All Genetics}

http://nn.neurology.org//cgi/collection/all_genetics All Immunology

http://nn.neurology.org//cgi/collection/all_immunology

\section{Autoimmune diseases}

http://nn.neurology.org//cgi/collection/autoimmune_diseases

\section{MRI}

http://nn.neurology.org//cgi/collection/mri

Information about reproducing this article in parts (figures,tables) or in its entirety can be found online at:

http://nn.neurology.org/misc/about.xhtml\#permissions

Information about ordering reprints can be found online: http://nn.neurology.org/misc/addir.xhtml\#reprintsus

Neurol Neuroimmunol Neuroinflamm is an official journal of the American Academy of Neurology.

Published since April 2014, it is an open-access, online-only, continuous publication journal. Copyright

Copyright $\odot 2021$ The Author(s). Published by Wolters Kluwer Health, Inc. on behalf of the American Academy of Neurology.. All rights reserved. Online ISSN: 2332-7812.

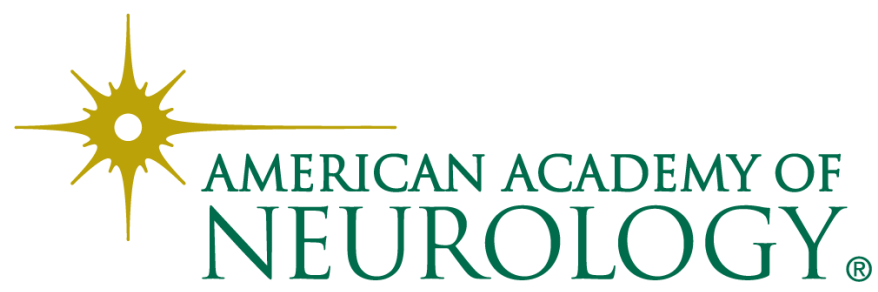

